\title{
Effect of Rainfall Intensity on Directional Splash Erosion in Clay Loam Soil under Simulated Condition
}

\author{
Virendra N. Barai ${ }^{1 *}$, Gajanan U. Satpute ${ }^{2}$ and Atul A. Atre ${ }^{3}$
}

${ }^{183}$ Dept. of SWCE, Mahatma Phule Krishi Vidyapeeth, Rahuri, Ahmednagar, Maharashtra (413 722), India

${ }^{2}$ Dept. of SWCE, Dr. Panjabrao Deshmukh Krishi Vidyapeeth, Akola, Maharashtra (444 104), India

\section{Corresponding Author}

Virendra N. Barai

e-mail: vnbarai@gmail.com

\author{
Article History \\ Article ID: $3 \mathrm{C0115}$ \\ Received in $11^{\text {th }}$ September, 2017 \\ Received in revised form $19^{\text {th }}$ December, 2017 \\ Accepted in final form $21^{\text {st }}$ January, 2018
}

\begin{abstract}
An attempt has been made to quantify splash detachment for various combinations of land slopes and rainfall intensities with the help of rainfall simulation system and modified Morgan's splash cup. The clay loam soil was used to study the splash erosion. Uniformity coefficient of simulated rainfall was above $70 \%$ for all the six selected rainfall intensities viz. $7.75,5.8,4.23,3.28,2.04$ and $1.07 \mathrm{~cm} \mathrm{~h}^{-1}$, which is acceptable. The directional splash soil loss rate $\left(\mathrm{kg} \mathrm{ha}^{-1}\right)$, i.e. upslope and down slope were found increasing with increase in rainfall intensity and land slope. The rate of increase in down slope splash was comparatively more than upslope. The highest soil splash i.e. 17898 $\mathrm{kg} \mathrm{ha}^{-1}$ was observed for combination of $10 \%$ land slope and $7.75 \mathrm{~cm} \mathrm{~h}^{-1}$ rainfall intensity in clay loam soil. The results obtained showed that maximum vertical movement of splashed material was $89 \mathrm{~cm}$ in clay loam soil, for the combination of rainfall intensity $7.75 \mathrm{~cm} \mathrm{~h}^{-1}$ and land slope $10 \%$. The maximum horizontal movement of splashed material was found $111.0 \mathrm{~cm}$ for the combination of rainfall intensity $7.75 \mathrm{~cm} \mathrm{~h}^{-1}$ and land slope $10 \%$. The Splashed soil material was spread near about $111.0 \mathrm{~cm}$ in the down slope direction and $75.5 \mathrm{~cm}$ in the upslope direction which highlights the need to modify the size of splash cup to study the realistic soil movement during splash erosion.
\end{abstract}

Keywords: Splash erosion, modified morgan's splash cup, clay loam

\section{Introduction}

In recent years agriculture and food production have intensified the soil erosion due to population increase and human activities transformation, so that about 75 billion tons of soils are eroded from lands each year (Bayramin et al., 2003). Water erosion is a process by which soil aggregates and primary particles are detached from the soil matrix, transported down slope by raindrops and flowing water, and deposited under certain energy-limiting conditions. Four basic detachment and transport processes have been identified, including detachment by raindrops, detachment by flowing water, transport by raindrops, and transport by flowing water. Splash erosion is recognized as the first stage in a soil erosion process that results from the impact of rain drops. Soil particles are separated by rain drops and are transmitted by runoff. Splash process can cause movement of soil particles, which show less cohesive forces (Wuddivira et al., 2009).

Splash erosion is a complex process including the detachment of soil particles by raindrops followed by splash transport of a part of the detached particles. Splash is responsible for initiating water erosion, since it is the first erosion to occur when an erosive rainfall event takes place (Torres et al.,
1994); Though soil erosion is usually associated primarily with surface runoff, other studies have shown that under certain topographical conditions, soil detachment is influenced more by raindrop impact than by overland flow. Rose (1960) observed that soil loss increases ten times when water is applied as a spray in comparison with the same application rate as surface flow. Therefore, although surface runoff is usually considered the major soil moving agent, raindrop erosion also plays an important role in not only detaching the soil particles but also causing soil movement even before the runoff starts (Quansah, 1981).

One very effective approach to the study of soil erosion processes and the analysis of possible remedial strategies involves the use of rainfall simulator. Drop velocity is important in designing a rainfall simulator. Drops from natural rainfall are at terminal velocity when they hit the soil surface (Meyer and McCune, 1958). Therefore, a rainfall simulator must create drops of adequate size and velocity to simulate the same condition, indicating the importance between an adequate and related fall distance and drop size distribution. Direct relationship exists between drop diameter and fall distance (Laws, 1941). The classical method for quantifying splash erosion relies on the use of splash cups, or small traps 
that collect soil particles detached and transported by splash (Morgan, 1978; Legout et al., 2005)

Kanase et al. (2012) selected three rainfall intensities for specific time of exposure. The movements of splashed soil particles were observed in horizontal direction as 20-22, 30-38 and 55-60 cm for rainfall intensities of 5.96, 6.66 and $7.64 \mathrm{~cm} \mathrm{hr}^{-1}$ respectively. Similarly the vertical movements of splashed soil particles were observed to be 12-14, 20-22 and $25-30 \mathrm{~cm}$ for rainfall intensities of 5.96, 6.66 and 7.64 $\mathrm{cm} \mathrm{hr} \mathrm{h}^{-1}$ respectively. The horizontal and vertical movement of splashed soil particles increased with increase in rainfall intensity.

Martinez-Murillo et al. (2013) studied soil erosion of the western Mediterranean badlands through rainfall simulation experiments. Results show that rainfall intensity, runoff coefficient, and slope angle have a positive influence on sediment concentration and sediment detachment; in the case of rock fragment cover, its influence is variable according to the soil cover percentage. Rainfall simulations increase our understanding of the temporal and spatial variability of the soil erosion processes. However, rainfall simulation provides mostly qualitative rather than quantitative information because of the small plot size and the simulated rainfall characteristics due to facility for repeating experiments and recording a high quantity of data in short time.

The importance of the soil erosion problem and its impact on soil management and conservation led to the recent study, in which an attempt has been made to study splash detachment process for various combination of land slopes and rainfall intensities with the help of rainfall simulation system and modified Morgan's splash cup. The present research work was undertaken during 2013 in the Department of Soil and Water Conservation Engineering, Dr. A.S. College of Agricultural Engineering, MPKV, Rahuri. The following objectives selected for the experiment viz. to study the effect of land slope on splash erosion, to study the movement of splashed material in vertical and horizontal directions under different rainfall intensities, to develop the device for measurement of splash erosion and to quantify the splash soil loss with developed splash cup.

\section{Materials and Methods}

The experimental set up consists of rainfall simulation system, modified Morgan's splash cup and cover for protecting the cup. A turbine nozzle is used for simulation of rainfall. The height of nozzle is kept $4.2 \mathrm{~m}$ from the ground surface. Lance was connected to the PVC pipe. The details of nozzle are given as below. Version Standard: $61 \mathrm{~mm}$ body with $\varnothing 1.0$ $\mathrm{mm}$ with ball joint. Materials-brass, made by company Shree Parmeshwar Machine Tools (PMT), Vavdi, Rajkot (Gujarat) with an excellent micronization. A pressure gauge having a dial diameter of $6 \mathrm{~cm}$ was mounted on main supply line on a lance just near the nozzle to monitor the water pressure. In the present study, the pressure was varied from $0.2-2.8 \mathrm{~kg} \mathrm{~cm}^{-2}$ at an equal increment of $0.1 \mathrm{~kg} \mathrm{~cm}^{-2}$. Calculations for rainfall intensity were based on amount of water collected during each time interval. Rainfall intensity was calculated for water pressure range from $0.2-2.8 \mathrm{~kg} \mathrm{~cm}^{-2}$ at an increment of $0.1 \mathrm{~kg}$ $\mathrm{cm}^{-2}$. The required water pressure at increment of $0.1 \mathrm{~kg} \mathrm{~cm}^{-2}$ was adjusted using flow regulating valve. The total quantity of water received through the nozzle at desired water pressure was collected in plastic bucket for 2 minute duration. This study was conducted with six rainfall intensities i.e. 7.75, 5.80, $4.23,3.28,2.04$ and $1.07 \mathrm{~cm} \mathrm{hr}^{-1}$ for five different land slopes i.e. 1, 3, 5, 7 and $10 \%$. The Clay loam textured soil was used for the experiment. The uniformity coefficient of simulated rainfall was determined for all selected rainfall intensities using relationship developed by Christiansen (1942). The raindrop size was determined by 'flour pellet' method (Hudson, 1964). Modified Morgan's splash cups were fabricated by changing the diameter of catching tray as $600 \mathrm{~mm}$ and keeping all other dimensions same. The floor of the catching tray was replaced with a wire mesh sheet covered with muslin cloth. This will allow free drainage of the rainwater whilst still allowing the collection of splashed particles. Two semicircular rings were made with G.I. wire to fix the muslin cloth over catching tray properly and for easy replacement of muslin cloth. When set up on a horizontal surface the apparatus will catch all particles splashed from the soil in the inner cylinder for distances less than the radius of the catching tray.

\subsection{Determination of splash soil loss}

For estimating the splash soil loss, splashed soil is collected separately from the up slope and down slope compartments of the catching tray. Muslin cloth was used to cover the catching tray. Two separate muslin clothes were used for upslope and down slope compartment. The muslin cloth covered over the floor of catching tray was removed by removing the semicircular G.I. wire frame, and washed with water in a bucket to detach the soil particles. The muslin cloth which was kept below and surrounding the splash cup at a distance about $1.5 \mathrm{~m}$ on both sides from the centre of soil plot also removed and washed with water in bucket. This water with splashed soil is taken in sample bottles of 1000 and 1500 $\mathrm{ml}$ capacity and kept for $24 \mathrm{hrs}$ for settlement of suspended soil particles. The clear suspension was decanted off and remaining sample with little water is stirred thoroughly and filtered. Soil on filter paper was oven dried at $105^{\circ} \mathrm{C}$ for $24 \mathrm{~h}$ and weighed. The upslope and down slope weights combined are a measure of splash detachment. Data may be expressed on a unit width per unit time or a unit area per unit time basis (Morgan, 1978).

\subsection{Determination of horizontal and vertical movement of splashed soil particles}

The modified Morgan's splash cup was installed on a soil plot by giving the desired slope just below the sprinkling unit (nozzle). Soil plot was covered by muslin cloth of suitable size. 
Antecedent moisture content at pre-wetted condition was selected. Pre-wetting was done by applying water through the drain for $24 \mathrm{~h}$. The pre-wet soil was immersed in the inner hollow cylinder up to full depth. The six rainfall intensities viz. $7.75,5.8,4.23,2.98,2.01$ and $1.07 \mathrm{~cm} \mathrm{hr}^{-1}$ were selected to test the movement of splashed particles with two replications. Simulated rainfall at various rainfall intensities was continued till the runoff takes place from the soil placed in the inner cylinder of length $11 \mathrm{~cm}$. The splashed soil particles from inner cylinder of modified Morgan's cup which marked the stains on muslin cloth. The range of horizontal movement of splashed soil particles was measured by measuring tape. The vertical splash boards arranged adjoining the modified Morgan's splash cup received the splashed soil particles. The vertical distance was measured, where the soil particles strikes on the graduated marking of the splash board. The horizontal and vertical movements of splashed soil particles were observed under selected six rainfall intensities.

\section{Results and Discussion}

This study was undertaken to observe the soil loss due to splash as influenced by rainfall intensity and land slope for bare soil condition under simulated rainfall. Accordingly, modified Morgan's splash cup with outer diameter $60 \mathrm{~cm}$ and partitioned into two compartments i.e. up slope and down slope was used to quantify directional splash. This study was conducted at six rainfall intensities i.e. 7.75, 5.80, 4.23, $3.28,2.04$ and $1.07 \mathrm{~cm} \mathrm{hr}^{-1}$ and for five different land slopes i.e. 1, 3, 5, 7 and 10\%. The Clay loam textured soil was used for the experiment and height of rainfall simulator was kept constant. The suitability of simulator is tested by determining the uniformity coefficients at different rainfall intensities. The time of exposure was maintained up to runoff generation from soil filled in inner cylinder. The splash soil loss for different combinations of rainfall intensities and land slopes were observed in two replications and the results obtained are described below. The uniformity coefficient of simulated rainfall under different rainfall intensities was 71.80 to $89.75 \%$ for rainfall intensities 11.22 to $1.07 \mathrm{~cm} \mathrm{~h}^{-1}$, which are more than $70 \%$ and hence acceptable (Esteves et al., 2000). It is observed that the raindrop size increased with increasing rainfall intensity. The rain drop size observed from $1.48 \mathrm{~mm}$ to $3.24 \mathrm{~mm}$ for the range of rainfall intensities from $1.07 \mathrm{~cm}$ $\mathrm{h}^{-1}$ to $7.75 \mathrm{~cm} \mathrm{hr}^{-1}$ respectively. For different combinations of rainfall intensities and land slopes up to the runoff generation, the soil splash in both the direction i.e. up slope and down slope were collected separately according to the procedure described under material and methods. The collected soil splash in different direction is then converted to splash soil loss rate in $\mathrm{kg} \mathrm{ha}^{-1}$. The values thus obtained are given in Table 1.

From Table 1, it is found that with increase in land slopes, splash soil loss rate increased for all selected rainfall intensities for the clay loam soil. The splash soil loss rate increased from 7643-17898 $\mathrm{kg} \mathrm{ha}^{-1}$ as land slope increased from $1-10 \%$ at
Table 1: Directional splash soil loss rate $\left(\mathrm{kg} \mathrm{ha}^{-1}\right)$ at different combinations of rainfall intensity and land slopes in clay loam soil

\begin{tabular}{|c|c|c|c|c|c|c|c|}
\hline \multirow{2}{*}{$\begin{array}{l}\text { Land } \\
\text { slope } \\
(\%)\end{array}$} & \multirow{2}{*}{$\begin{array}{l}\text { Direc- } \\
\text { tion of } \\
\text { splash } \\
\text { soil loss }\end{array}$} & \multicolumn{6}{|c|}{ Rainfall intensities $\left(\mathrm{cm} \mathrm{hr}^{-1}\right)$} \\
\hline & & 7.75 & 5.8 & 4.23 & 3.28 & 2.04 & 1.07 \\
\hline \multirow[t]{3}{*}{1} & $\begin{array}{l}\text { Up } \\
\text { slope }\end{array}$ & 1592 & 1338 & 1210 & 1083 & - & - \\
\hline & $\begin{array}{l}\text { Down } \\
\text { slope }\end{array}$ & 6051 & 2739 & 1465 & 1210 & - & - \\
\hline & Total & 7643 & 4140 & 2739 & 2293 & - & - \\
\hline \multirow[t]{3}{*}{3} & $\begin{array}{l}\text { Up } \\
\text { slope }\end{array}$ & 2611 & 1465 & 1338 & 1401 & - & - \\
\hline & $\begin{array}{l}\text { Down } \\
\text { slope }\end{array}$ & 6561 & 2866 & 1975 & 1656 & - & - \\
\hline & Total & 9172 & 4331 & 3376 & 3057 & - & - \\
\hline \multirow[t]{3}{*}{5} & $\begin{array}{l}\text { Up } \\
\text { slope }\end{array}$ & 3121 & 1847 & 1274 & 1656 & - & - \\
\hline & $\begin{array}{l}\text { Down } \\
\text { slope }\end{array}$ & 7771 & 3248 & 2803 & 2611 & - & - \\
\hline & Total & 10892 & 5096 & 4076 & 4268 & - & - \\
\hline \multirow[t]{3}{*}{7} & $\begin{array}{l}\text { Up } \\
\text { slope }\end{array}$ & 3885 & 2611 & 2994 & 2357 & - & - \\
\hline & $\begin{array}{l}\text { Down } \\
\text { slope }\end{array}$ & 8280 & 6242 & 3694 & 3121 & - & - \\
\hline & Total & 12166 & 8854 & 6688 & 5478 & - & - \\
\hline \multirow[t]{3}{*}{10} & $\begin{array}{l}\text { Up } \\
\text { slope }\end{array}$ & 6051 & 5248 & 2739 & 2675 & - & - \\
\hline & $\begin{array}{l}\text { Down } \\
\text { slope }\end{array}$ & 11847 & 7261 & 4459 & 3439 & - & - \\
\hline & Total & 17898 & 10510 & 7197 & 6115 & - & - \\
\hline
\end{tabular}

$7.75 \mathrm{~cm} \mathrm{hr}^{-1}$ rainfall intensity in clay loam soil. Similar trend was observed for all rainfall intensities with increase in land slope. The maximum value of splash soil loss rates were observed at $10 \%$ land slope, whereas minimum values were observed at $1 \%$ land slope for all selected rainfall intensities. It is revealed from Table 1 with increase in rainfall intensity, upslope and down slope splash soil loss rates increased for all selected land slopes viz., 1, 3, 5, 7 and 10\%; thus increase in total splash soil loss rate (up slope+down slope) with increase in rainfall intensity for all given land slopes. Similar results have been obtained and reported by Akurde (2009). Splash soil loss was not found for the intensities 2.04 and $1.07 \mathrm{~cm} \mathrm{~h}^{-1}$. This conclusion confirmed the findings reported by Hudson (1971).

The observations were taken with selected rainfall intensities $7.75,5.80,4.23,3.28$ and $1.07 \mathrm{~cm} \mathrm{hr}^{-1}$ for different land 
slope. The horizontal and vertical movements of splashed soil particles in down slope and up slope directions were observed. The horizontal spread of splashed soil material was about $111.0 \mathrm{~cm}$ in the down slope direction and $75.5 \mathrm{~cm}$ in the up slope direction, which is beyond the diameter of modified Morgan's splash cup. In order to get realistic values of splashed soil loss for detail studies on soil erosion processes the dimensions of splash cup need to be increased.

\section{Conclusion}

The splash soil loss rate increased with increase in rainfall intensity for all selected land slopes of 1, 3, 5, 7 and $10 \%$. The splash soil loss rate increased with increase in land slopes for all selected rainfall intensities of $3.28,4.23,5.8$ and $7.75 \mathrm{~cm} \mathrm{hr}$ ${ }^{1}$. It ranges from $2293 \mathrm{~kg} \mathrm{ha}^{-1}$ to $17898 \mathrm{~kg} \mathrm{ha}^{-1}$, when intensity varies from 3.28 to $7.75 \mathrm{~cm} \mathrm{hr}^{-1}$. The rainfall intensities below $2.04 \mathrm{~cm} \mathrm{~h}^{-1}$ do not produce splash soil erosion. The splashed soil loss towards down slope compared to up slope was in the range of 1.12-3.8 times for the combination of rainfall intensities and land slopes. The greater amounts of soil particles were splashed towards down slope because of gravity force compared to up slope.

\section{References}

Akurde, A.B., 2009. Effect of rainfall intensity and land slope on splash erosion under simulated rainfall. M. Tech. thesis (SWCE) submitted to Mahatma Phule Krishi Vidyapeeth, Rahuri.

Bayramin, I.O., Baskan, D., Parlak, M., 2003. Soil erosion assessment with CONA model: case study Beypazri area. Turkish Journal of Agriculture 27, 105-116.

Christiansen, J.E., 1942. Irrigation by sprinkling, Bulletin 670. Berkely Cal.: Univ. California Agricultural Experiment Station.

Esteves, M., Planchon, O., Lapetite, J.M., Silveral, N., Cadet,
P., 2000. The Emire large rainfall simulator: design and field testing. Earth Surface processes and Landform 25, 681-690.

Hudson, N.W., 1964. The Flour pellet method for measuring size of raindrops. Research bulletin 4, Department of Conservation, Salisbury, Rhodes.

Hudson, N.W., 1971. A textbook of Soil Conservation. B. T. Batsford Limited, 50, 52, 58-60.

Laws, J.O., 1941. Measurements of fall velocity of water drops and raindrops. Transactions of American Geophysics Union 22, 709-721.

Legout, C., Leguedois, S., Malam-Issa, O., Le Bissonnais, Y., 2005. Splash distance and size distributions for various soils. Geoderma 124(3), 279-292.

Martinez -Murillo, J.F., Nadal-Romero. E., Regues, D.,Cerda, A., Poesen, J., 2013. Soil erosion and hydrology of the western Mediterranean badlands throughout rainfall simulation experiments: A review. Catena 106, 101-112

Meyer, L.D., McCune, D.L., 1958. Rainfall simulation for runoff plots. Journal of Agricultural Engineering 39, 644-648.

Morgan, R.P.C., 1978. Field studies of rain splash erosion. Earth Surface Processes and Landform 3(3), 295-299.

Quansah, C., 1981. The effect of soil type, slope, rain intensity and their interactions on splash detachment and transport. Journal of Soil Science 32, 215-224.

Rose, C.W., 1960. Soil detachment caused by rainfall. Canadian Journal of Soil Science 89, 28-34.

Torres, S.D., Porrà, J.M., Creutin, J.D., 1994. A general formulation for raindrop size distribution. Journal of Applied Meteorology 33, 1494-1502.

Wuddivira, M.N., Stone, R.J., Ekwue, E.I., 2009. Clay, organic matter and wetting effects on splash detachment and aggregate breakdown under intense rainfall. Soil Science Society of American Journal 73, 226-232. 